\title{
Do olfactory cues mediate interactions between rodents on northern shortgrass prairie?
}

\author{
Paul Stapp and Beatrice Van Horne
}

\begin{abstract}
We counted captures of free-ranging deer mice (Peromyscus maniculatus) in odor-baited traps to determine whether deer mice use olfactory cues to detect and evade grasshopper mice (Onychomys leucogaster), a predator and possible competitor on northern shortgrass prairie. Avoidance was measured using the frequency of captures in traps containing grasshopper mouse odors compared with that in traps containing odors of an innocuous rodent (Reithrodontomys megalotis) and in clean traps. We predicted that deer mice would be most deterred by odors in areas where grasshopper mice were common, and during winter, when alternative prey for grasshopper mice are less abundant. We also expected reproductive females to show greater avoidance because of the vulnerability of litters in burrows. Surprisingly, deer mice showed no evidence of avoidance in any experiments. These results are consistent with trapping records from capture-recapture studies on our site. We assert that the presence of grasshopper mice may affect the surface activity of deer mice, but that deer mice apparently do not use olfactory cues to avoid grasshopper mice. Taken with other studies noting the lack of avoidance of predator odors by deer mice and similar species, our results suggest that the response of rodents to predator odors is more variable than was previously appreciated.
\end{abstract}

Résumé : Nous avons compté le nombre de Souris sylvestres (Peromyscus maniculatus) capturées dans des pièges à odeurs pour déterminer si ces souris utilisent les odeurs pour repérer et éviter les Souris-à-sauterelles boréales, Onychomys leucogaster, prédateurs et compétiteurs probables dans la prairie boréale d'herbes courtes. La réaction d'aversion a été mesurée par comparaison de la fréquence des captures dans les pièges à odeurs de souris-à-sauterelles à la fréquence des captures dans les pièges à odeurs d'un rongeur inoffensif (Rheithrodontomys megalotis), ou dans les pièges propres. Nous avons posé en hypothèse que les souris fuiraient les odeurs des souris-à-sauterelles, surtout dans les zones où ces animaux sont communs, et au cours de l'hiver, au moment où les proies de rechange des souris-à-sauterelles sont moins abondantes. Nous nous attendions aussi à ce que les femelles en phase reproductrice évitent encore davantage les pièges à odeurs de souris-à-sauterelles à cause de la vulnérabilité de leur progéniture dans les terriers. Étonnamment, les souris n'ont montré d'aversion particulière pour aucune des odeurs. Ces résultats concordent avec les résultats des piégeages effectués au cours d'expériences de capture-recapture sur le même territoire. Les souris-à-sauterelles peuvent affecter l'activité de surface des Souris sylvestres, mais celles-ci ne semblent pas se guider sur les odeurs pour éviter les souris-à-sauterelles. Combinés aux résultats d'autres études qui dénotent l'absence d'aversion pour les odeurs des prédateurs chez les Souris sylvestres et chez d'autres espèces semblables, nos résultats indiquent que la réaction des rongeurs aux odeurs des prédateurs est plus variable qu'on ne l'avait cru à ce jour. [Traduit par la Rédaction]

\section{Introduction}

Numerous studies have documented the importance of olfactory cues in mediating social and interspecific interactions of small mammals (Drickamer et al. 1992 and references therein). Many rodents use odor cues to detect and avoid both potential competitors (Daly et al. 1980; Drickamer et al. 1992) and mammalian predators (Madzer et al. 1976; Dickman 1992; Drickamer et al. 1992; Jędrzejewski et al. 1993; Nolte et al. 1994; Zimmerling and Sullivan 1994; and references therein). Such cues may be particularly useful for prey species because they allow individuals to recognize and evade predators without visual or direct contact, and because they may remain in an area for an extended period of time and provide information on the temporal status of a predator's activity.

Received May 12, 1995. Accepted September 22, 1995.

P. Stapp ${ }^{1}$ and B. Van Horne. Department of Biology, Colorado State University, Fort Collins, CO 80523, U.S.A.

1 Author to whom all correspondence should be addressed (e-mail: stapp@lamar.colostate.edu).
The northern grasshopper mouse (Onychomys leucogaster) and deer mouse (Peromyscus maniculatus) are nocturnal murid rodents that inhabit desert and semi-arid grasslands of the western United States and southwestern Canada. Grasshopper mice are unusual among North American rodents in being mostly arthropodivorous (McCarty 1978), and numerous studies suggest that they prey on other rodents, including deer mice (Bailey and Sperry 1929; Egoscue 1960; Horner et al. 1965; Ruffer 1968; Cole and Wolfe 1970; Flake 1971; Rebar and Conley 1983). In many regions, deer mice are omnivorous and consume many insects; this dietary overlap with grasshopper mice may therefore result in interspecific competition. Adult grasshopper mice are approximately $33 \%$ larger than adult deer mice (Armstrong 1972) and, as potential predators, their presence may influence the surface activity of deer mice. Rebar and Conley (1983) found that kangaroo rats (Dipodomys ordii) shifted microhabitat use in the presence of grasshopper mice, and it seems likely that grasshopper mice may have a similar or more significant impact on deer mice because of their greater similarity of size and ecology.

If grasshopper mice pose a threat to other small mammals, 
one might expect rodents such as deer mice to be able to detect and avoid grasshopper mice prior to contact. Because deer mice may use odor cues in interactions between both conspecifics and other rodents (Daly et al. 1980; Drickamer 1984), and because grasshopper mice possess a strong musky odor that may be deposited on the substrate in the form of urine, feces, and territorial signposts (Ruffer 1965), we predicted that avoidance could be effected through olfactory cues.

We compared the frequency of captures of deer mice in traps containing fecal and urinary odors of grasshopper mice or western harvest mice (Reithrodontomys megalotis) and in clean traps to determine whether deer mice use olfactory cues to avoid grasshopper mice on shortgrass prairie. We focused largely on the behavior of deer mice because they co-occur with grasshopper mice on many prairie cover types, and because these two species are frequently the most abundant mice on our study area in north-central Colorado. Harvest mice are present in many areas of high population densities of deer mice, and were chosen to represent a rodent odor that was presumably innocuous. We tested four predictions: (1) deer mice would be captured more frequently in traps containing harvest mouse odors or in clean traps than in traps containing odors of grasshopper mice; (2) odors of grasshopper mice would be a greater deterrent to deer mice in areas where grasshopper mice are common than to mice living in areas where grasshopper mice are rare (i.e., avoidance is enhanced by prior experience and continued exposure); (3) because females with litters in burrows are probably more vulnerable to predation by grasshopper mice, female deer mice, particularly those in reproductive condition, would be more likely to avoid traps containing grasshopper mouse odors; (4) deer mice are more likely to be preyed upon by grasshopper mice during winter, when the availability of preferred prey (arthropods) is reduced, and hence will show greater avoidance during winter than in summer.

\section{Methods}

\section{Study area}

Our experiments were conducted from June to December 1993 on the Central Plains Experimental Range, located approximately $60 \mathrm{~km}$ northeast of Fort Collins, Colorado, U.S.A. $\left(40^{\circ} 49^{\prime} \mathrm{N}\right.$, $\left.107^{\circ} 47^{\prime} \mathrm{W}\right)$. The climate is semi-arid: mean monthly temperatures range from $-5^{\circ} \mathrm{C}$ in January to $22^{\circ} \mathrm{C}$ in July, and most of the $321 \mathrm{~mm}$ of annual precipitation falls in brief summer thunderstorms (Coffin and Lauenroth 1990). The topography consists of flat uplands separated by shallow swales and broad seasonal drainages. Upland vegetation is open grassland and is dominated by Bouteloua gracilis. Lowland areas typically contain an abundance of fourwing saltbush (Atriplex canescens) as well as a variety of small shrubs. The species diversity and population density of rodents are greater in lowland areas than in uplands (Lindquist et al. 1995), although rodent biomass generally is lower on shortgrass prairie than on other North American grasslands (Grant and Birney 1979). Densities of deer mice and grasshopper mice typically range from 1 to $4 /$ ha and rarely exceed $6 /$ ha.

\section{Odor-response experiments}

We conducted experiments in June and August 1993 to examine the response of deer mice to trap odors on a trapping area where grasshopper mice were rarely captured (mean $\pm \mathrm{SE})(0.1 \pm 0.1 / 100$ trap-nights (mean $\pm \mathrm{SE}$ ); $n=5$ trapping sessions of $500-720$ trap- nights each) and on areas where grasshopper mice were relatively common ( $1.0 \pm 0.3 / 100$ trap-nights; $n=5$ sessions $)$. To test the hypothesis that there are seasonal differences in avoidance, we repeated the experiment in December 1993 on the site without grasshopper mice (a widespread decline in the abundance of deer mice unfortunately resulted in few or no captures on sites with grasshopper mice in winter 1993). Deer mice and harvest mice were relatively common on the site where grasshopper mice were absent $(2.8 \pm 0.2$ and $2.1 \pm 0.4 / 100$ trap-nights, respectively; $n=5$ sessions), which was located in an area with fine-textured soils, dense cover of large saltbush, and little exposed soil. The grasshopper mouse site used for the June experiment was located on an area with widely spaced saltbush, numerous small shrubs, and numerous soil disturbances. Because deer mice had become extremely rare on this location by August, for the second experiment the site without grasshopper mice was moved to a nearby area dominated by small soapweed (Yucca glauca) and perennial bunchgrasses (e.g., Stipa comata). Grasshopper mice were captured in equal numbers on both sites, and the number of deer mice on the second grasshopper mouse site was similar to that on the first of these sites in June. All areas (2.25-3.24 ha) had been trapped on a regular basis since 1992 .

Sherman live traps $(7.6 \times 8.9 \times 22.9 \mathrm{~cm}$; folding $)$ were used in all experiments. To remove any residual odors before experiments, all traps were disassembled, scrubbed clean with warm water and dishwashing soap, and rinsed in a mixture of warm water and baking soda. To obtain odors for traps, we collected soiled raw cotton and feces from traps in which grasshopper mice and harvest mice had been captured off-site. These materials were immediately placed in separate plastic storage bags and stored in a freezer (Drickamer et al. 1992). Clean cotton was placed in traps assigned to contain no rodent odors. All subsequent handling of cotton was conducted with latex gloves or through clean plastic bags. Like materials were combined, and we did not separate cotton by sex or age of the individuals captured. Traps were provided with the freshest materials available and unused materials were discarded after 1 month in the freezer.

At the beginning of each experiment, we baited traps with a small ball (ca. $5 \mathrm{~g}$ ) of peanut butter and oats, which was wrapped in wax paper and hung from the back of the trap. This technique prevented loose bait from blocking treadles and causing trap malfunctioning and allowed us to detect traps that had been visited but not tripped. Traps were supplied with one of the three odors by placing a small piece (ca. $2.5 \mathrm{~g}$ ) of cotton at the rear of the trap. We placed traps at grid stations where deer mice had been captured consistently during 4 or 5 recent nights of trapping. Each of the three contained a different odor and traps were placed $10 \mathrm{~cm}$ apart and faced inward in spoke-like fashion. The position of each trap was determined randomly prior to setting the traps. We set 20 trapsets per grid in the June experiment, 13-15 per grid in August, and $11-15$ in December. Traps were set for 3 consecutive nights during each experiment and sites were trapped concurrently.

We set traps at dusk and checked them at approximately 30-min intervals until 01:00 and approximately hourly thereafter until dawn or whenever we heard traps close (to prevent multiple captures at a triad). When a mouse was captured, we replaced the trap with a fresh one with the same odor, checked the remaining traps for evidence of trap malfunction, and rerandomized the positions of the traps. We determined the age, sex, and reproductive status (obvious testes for males; evidence of pregnancy or lactation for females) of mice and held them in traps until they were released the following morning at the location of capture.

Odor preference was indicated by capture in a trap containing a particular odor cue. Captures of deer mice were included in analyses when only deer mice were captured at a station and when only a single trap was closed. We also included cases (14 captures) in which a mouse was captured in a trap and a second trap had 
Fig. 1. Percentages of captures of deer mice (Peromyscus maniculatus) in traps containing odors of northern grasshopper mice (Onychomys leucogaster) and western harvest mice (Reithrodontomys megalotis) and in traps with no odors in experiments conducted in June, August, and December 1993 on the Central Plains Experimental Range. Open bars denote experiments in which grasshopper mice were extremely rare (19 and 26 captures for June and August, respectively), whereas solid bars denote experiments in which grasshopper mice were abundant $(21,16$, and 25 captures for June, August, and December, respectively).

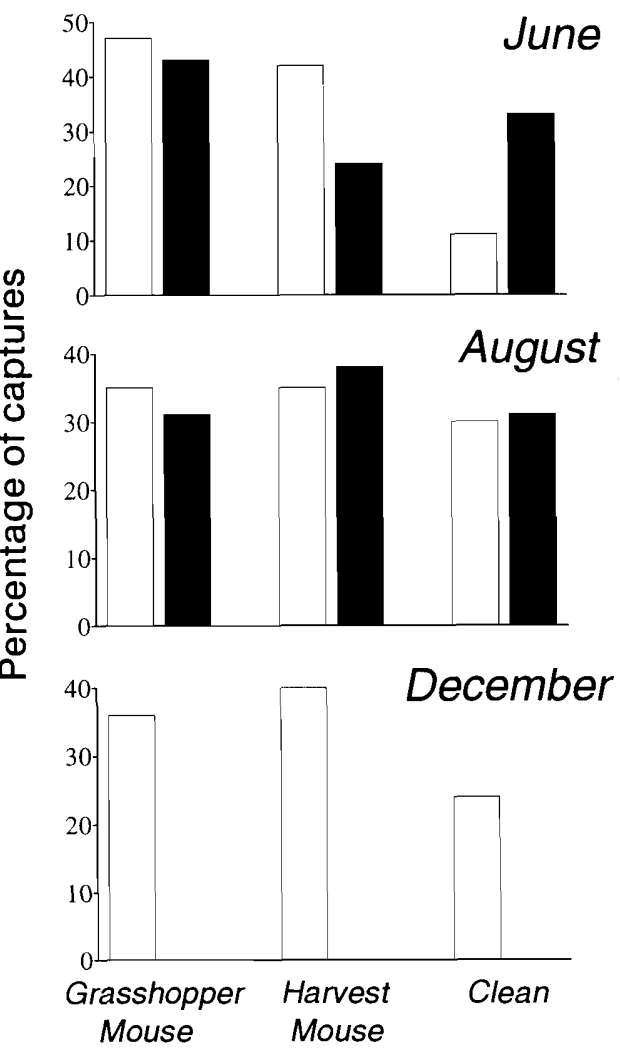

Trap odor

evidence of occupancy (partially eaten bait) but was not tripped; we assumed that the untripped trap had been entered first and therefore assigned captures from these sets to the odor of the untripped trap. We omitted instances in which one or more traps were empty and closed or multiple traps contained evidence of malfunction. We constructed linear logit models (Vepsäläinen and Savolainen 1988) using the CATMOD procedure of SAS (SAS Institute Inc. 1989) to test for the effects of presence or absence of grasshopper mice, sex, reproductive status, and season on the distribution of captures of deer mice among odor types. We also occasionally captured harvest mice and kangaroo rats $(D$. ordii) and used these captures to investigate whether these rodents exhibited any evidence of avoidance.

\section{Capture - recapture studies}

We searched for evidence of avoidance of grasshopper mice in trapping records from 30 mark - recapture trapping sessions conducted on the study area during 1992-1994. Trapping sessions consisted of 4 or 5 consecutive nights of live-trapping (228-720 trap-nights per session) on sites where both deer mice and grasshopper mice were frequently captured. Traps contained cotton for bedding, and although feces and soiled cotton were often removed from traps, they were not cleaned, so recent fecal and urinary odors likely remained in traps following captures.

The relative infrequency of captures of deer mice and grasshopper mice at the same trap stations is suggestive of avoidance, but we adopted a more conservative criterion that allowed us to distinguish avoidance from differences in microhabitat use. We identified trap stations where individuals of both species were captured during the same trapping session as suitable microhabitat for either species. Avoidance was indicated by the lack of additional captures of deer mice at one of these stations following capture of a grasshopper mouse. Instances in which a deer mouse was captured at a station where a grasshopper mouse had been captured on an earlier night provided evidence against avoidance. We also compared captures of both species to those of kangaroo rats, a granivorous rodent whose presence presumably does not affect deer mice (but see Heske et al. 1994), but which may avoid grasshopper mice (Rebar and Conley 1983).

\section{Results}

We captured 22 different deer mice in June (11 each on sites with and without grasshopper mice), 20 in August ( 7 and 13 on sites with and without grasshopper mice, respectively), and 13 on the site without grasshopper mice in December. Of the 107 captures used in our analyses, 41 were in traps containing odors of grasshopper mice, 38 were in traps containing harvest mouse odors, and 28 were in clean traps. Therefore, when all captures were pooled, there was no significant difference in the proportion of captures among odor types $(G=2.69, \mathrm{df}=2, P=0.26)$ and no evidence of avoidance of grasshopper mice. There was a tendency for mice to be more attracted to traps containing rodent odors than to clean traps $(G=2.58, \mathrm{df}=1, P=0.10)$, but this pattern was not consistent on all sites in all experiments (Fig. 1).

When only summer experiments were considered, there were no significant differences in the distribution of captures between areas where grasshopper mice were common and those where they were rare $\left(\chi^{2}=1.89, \mathrm{df}=2, P=0.39\right)$, nor were there differences between the distribution of captures between sites for the June and August experiments $\left(\chi^{2}=2.04\right.$, df $=2, P=0.36$; Fig. 1$)$. There was no evidence that deer mice on the site without grasshopper mice were more likely to avoid grasshopper mice during winter $\left(\chi^{2}=0.11, \mathrm{df}=2, P=0.95\right)$; this result did not change if summer experiments on both types of sites were included $\left(\chi^{2}=0.29\right.$, df $\left.=2, P=0.87\right)$.

Overall, more male than female mice were captured, but the odor preferences did not differ between the sexes $\left(\chi^{2}=\right.$ $0.60, \mathrm{df}=2, P=0.74$ ). Further, reproductive females were no more likely to avoid odors of grasshopper mice than were other mice $\left(\chi^{2}=0.86\right.$, df $\left.=2, P=0.65\right)$, regardless of whether they were in areas where grasshopper mice were abundant $\left(\chi^{2}=0.56, \mathrm{df}=2, P=0.76\right)$. Captures from the December experiment were not included in these analyses because no mice in reproductive condition were captured at that time.

Capture-recapture records from studies on the Central Plains Experimental Range also failed to show any evidence of avoidance by deer mice of residual odors of grasshopper mice in traps, although captures of different species at the same station during a trapping session were relatively uncommon (Table 1). Deer mice seemed to respond similarly to traps 
Table 1. Evidence of avoidance of residual trap odors from capture-recapture studies on the Central Plains Experimental Range in north-central Colorado.

\begin{tabular}{lccc}
\multicolumn{1}{c}{ Species 1 vs. species 2 } & $\begin{array}{c}\text { No. of captures at } \\
\text { the same station }\end{array}$ & Avoidance & No avoidance \\
\hline Deer mice (317) vs. grasshopper mice (470) & 28 & 4 & 15 \\
Deer mice (317) vs. kangaroo rats (276) & 20 & 5 & 10 \\
Kangaroo rats (276) vs. grasshopper mice (470) & 33 & 12 & 9 \\
\hline
\end{tabular}

Note: The results summarize captures from 30 trapping sessions of 4 or 5 nights each (ca. 10400 trap-nights) during 1992-1994 on areas where deer mice (Peromyscus maniculatus), grasshopper mice (Onychomys leucogaster), and kangaroo rats (Dipodomys ordii) were captured regularly. The numbers in parentheses indicate total numbers of captures of each species. The number of captures at the same station describes the number of captures of species 1 and species 2 at the same trap station during a given trapping session. After a capture of species 1 at a given trap station, species 1 avoided species 2 if, after a capture of species 2 , there were no additional captures of species 1 at that station. Lack of avoidance was indicated by capture of species 1 at a trap station after capture of species 2 at that station on an earlier night. Values for avoidance and lack of avoidance do not sum to the numbers of captures in common because some captures could not be classified.

Fig. 2. Percentages of incidental captures of western harvest mice (Reithrodontomys megalotis; 26 captures), northern grasshopper mice (Onychomys leucogaster; 10 captures), and Ord's kangaroo rats (Dipodomys ordii; 13 captures) in traps containing odors of northern grasshopper mice or western harvest mice or traps with no odors during three odor-response experiments conducted in 1993 on the Central Plains Experimental Range.

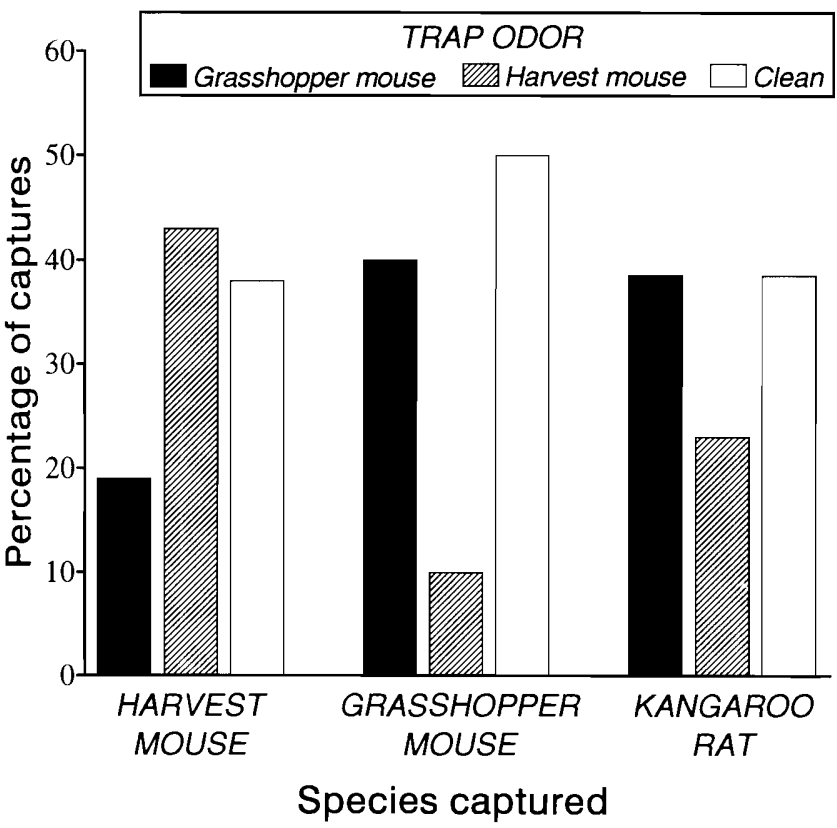

that had previously caught grasshopper mice and kangaroo rats, in that most captures at the same location provided no evidence of avoidance. Kangaroo rats and grasshopper mice were more frequently captured at the same stations, perhaps reflecting similarities in their microhabitat affinities, and there was a tendency for kangaroo rats to be deterred by traps in which grasshopper mice had been captured (Table 1). Incidental captures of kangaroo rats during odor-response experiments (Fig. 2), however, did not support this pattern. Harvest mice were captured less frequently in traps containing odors of grasshopper mice than in clean traps or in traps with harvest mouse odors $(G=2.54$, df $=1, P=0.10$;
Fig. 2), which suggests that they were capable of avoiding grasshopper mice using the cues provided.

\section{Discussion}

Although it has been hypothesized that grasshopper mice function as predators and competitors of deer mice on shortgrass prairie, we found no evidence in our odor-response experiments that deer mice use olfactory cues to avoid grasshopper mice. An analysis of trapping records from our mark-recapture studies supports this conclusion. The discriminatory abilities of deer mice may be such that mice could assess the age of the odors we provided, and therefore concluded that the grasshopper mouse odors were old and represented no threat. Our methods, however, were similar to those used in other studies that have demonstrated that rodents discriminate among and respond to odors in live traps (e.g., Daly et al. 1980; Dickman and Doncaster 1984; Stoddart and Smith 1986; Drickamer et al. 1992). Furthermore, results from an unpublished pilot study indicated that deer mice responded to the volatile cues we provided in traps. Incidental captures of harvest mice (Fig. 2) also suggest that they avoided grasshopper mice or were attracted to odors of conspecifics on the basis of odor cues provided, so our odor-baiting technique presumably was effective. We were not surprised that harvest mice showed evidence of avoidance; this species is approximately one-third the size of grasshopper mice and was most abundant on areas of shortgrass prairie when and where grasshopper mice were uncommon.

Contrary to our predictions, the response of deer mice to grasshopper mouse odors in traps was not influenced by previous exposure to grasshopper mice. In a similar study, Dickman (1992) reported that house mice (Mus domesticus) did not distinguish predator odors in areas without mammalian carnivores, but avoided these odors where predators were present. Mice may be more likely to avoid odors of those predators that they encounter most frequently or that pose the most significant threat (Madzer et al. 1976; Dickman 1992; Jędrzejewski et al. 1993). Others (Stoddart 1980, 1983; Dickman and Doncaster 1984), however, have suggested that the feces, urine, or anal-gland secretions of mammalian carnivores contain similar chemical cues that trigger 
avoidance by rodents, regardless of their ecological overlap or history of contact. Despite differences in the distribution of grasshopper mice among cover types of shortgrass prairie, over time there may be sufficient contact between deer mice and grasshopper mice to prevent deer mice on sites without grasshopper mice from losing their ability to detect grasshopper mouse odors. This phenomenon, however, would not explain the apparent lack of avoidance on all sites.

It is possible that deer mice rarely encounter grasshopper mice or are indifferent to their activity, so that there has been little selective pressure on deer mice to avoid grasshopper mice. Some reports of predation by grasshopper mice on deer mice and other rodents are from laboratory studies (Egoscue 1960; Ruffer 1968; Cole and Wolfe 1970), but predation evidently occurs under natural conditions. Flake (1971) reported that mammalian hair and tissue (including that of deer mice and kangaroo rats) accounted for $9-10 \%$ of the animal remains in the diet of grasshopper mice on our study area. Bailey and Sperry (1929) found the remains of deer mice, harvest mice, kangaroo rats, pocket mice (Perognathus sp.), and voles (Microtus sp.) in stomachs of field-caught grasshopper mice and concluded that small mammals may constitute $2-6 \%$ of the foods eaten. It is difficult to assess the importance of natural predation by grasshopper mice because predation has rarely been observed directly (but see Rebar and Conley 1983) and because grasshopper mice may selectively consume individuals or portions of prey that may not be readily identified in diet studies. For example, predation on nestling mice in burrows, such as that reported by Getz et al. (1992) for short-tailed shrews (Blarina brevicauda) on meadow voles (Microtus pennsylvanicus), may be difficult to detect because nestlings have little hair (Horner et al. 1965). Thus, even if attacks on adult mice were relatively infrequent, predation on litters could negatively impact deer mouse populations. In addition, results from a separate study (P. Stapp, in preparation) ${ }^{2}$ suggested that deer mice shift microhabitat use to avoid grasshopper mice, so it may be premature to conclude that interactions between these species are unimportant solely on the basis of the results of our odor-response experiment.

An alternative explanation is that deer mice either cannot distinguish odors of other rodents, or do not use olfactory cues in interspecific interactions. Deer mice use odor cues to identify and assess the reproductive condition of conspecifics (Gurnell and Little 1992 and references therein), but they may not distinguish consistently between heterospecific and neutral odors (Wuensch 1982). Daly et al. (1980) stated that deer mice differentiated between clean traps and those containing odors of reputed competitors (kangaroo rats), but they found evidence of avoidance only when the mouse's reproductive status was considered and only for the smaller of the two competitors studied. It is not clear, however, why reproductive status should affect the ability of mice to detect the odors of competitors, or why only reproductive mice would be attracted to these odors (Daly et al. 1980).

Given the carnivorous habits of grasshopper mice, our results support those from other researchers who have noted the lack of response of Peromyscus spp. to predator odors in

2 P. Stapp. Community structure of shortgrass-steppe rodents: an evaluation of the roles of intraguild predation and competition. In preparation. field experiments. Sullivan et al. (1988a) noted that deer mice entered traps containing odors from stoats (Mustela erminea) and red foxes (Vulpes vulpes), although the mice were not provided with a choice of odors and may have been attracted to baited traps. Madzer et al. (1976) similarly found that Peromyscus leucopus readily entered traps containing feces of weasels (Mustela frenata). The application of mustelid semiochemicals to forest plantations in British Columbia had no significant effect on the demography of deer mice (Zimmerling and Sullivan 1994).

In spite of this evidence, we cannot satisfactorily explain why olfactorally mediated predator avoidance would not be advantageous for deer mice, particularly when it is apparently employed by many other rodents. However, Old World wood mice (Apodemus sp.) also apparently do not differentiate between heterospecific and neutral odors (Stoddart and Smith 1984, 1986; Gurnell and Little 1992) and do not avoid traps containing predator odors (Stoddart 1976, 1980, 1983; Dickman and Doncaster 1984; Gorman 1984; Little 1985, ${ }^{3}$ cited in Robinson 1990; but see Robinson 1990). Peromyscus spp. and Apodemus spp. are similar in morphology, behavior, and life-history traits, and are often considered to be ecologically equivalent, at least in a broad sense (Montgomery 1989). Species of both genera typically exhibit moderate seasonal changes in abundance and are preyed upon by similar mammalian and avian predators (Montgomery 1989; Terman 1993). It is not clear, however, that predators are responsible for fluctuations in population size of Peromyscus spp. and Apodemus spp., at least to the degree suggested for other rodents whose populations exhibit multi-annual cycles (Microtus sp.: Henttonen et al. 1987; Erlinge 1987) or episodic irruptions (Mus sp.: Sinclair et al. 1990). Avoidance of predator odors is well documented in these latter groups (Sullivan et al. 1988a; Merkens et al. 1991; Dickman 1992; Drickamer et al. 1992; and references therein; but see Boonstra et al. 1982).

We speculate that differences in the odor responses of Peromyscus spp. and Apodemus spp. from those of other rodents may reflect an interaction between the behavior of some predators and prey population dynamics. For example, if mammalian predators responded to high prey densities or preferred species with the potential to reach high numbers, then selection should strongly favor individuals of those taxa that are alerted by and avoid predator cues. The evolution of odor avoidance could be enhanced in cyclic or irruptive rodents if, as suggested by Jegdrzejewski et al. (1993), the hunting success of predators declined with increasing prey abundance (Vermeij 1982). For individuals in relatively sparse or stable populations, encounters with predators and predator cues may be relatively infrequent or predator success rates may be high, so that there are few opportunities to associate successfully the threat of predation with olfactory cues and little difference in fitness between those individuals that react to predator odors and those that do not. For example, predator odors may not be useful to either Peromyscus spp. or Apodemus spp. in winter, when both may enter torpor (Jędrzejewski et al. 1992).

This scenario assumes that there is heritable variation in

3 D. Little. 1985. The effect of mink, Mustela vison, faeces on three species of rodents. B.Sc. (Hons.) thesis, University of Aberdeen, Aberdeen, Scotland. 
the response of individuals to olfactory cues, that individuals wary of predator odors contribute more to future generations than those that are not, and that predator success is usually negatively correlated with prey abundance. Our model may not be adequate to explain the avoidance of predator odors by other rodents (e.g., Thomomys talpoides, Sullivan et al. 1988b; Marmota monax, Swihart 1991; Aplodontia rufa, Epple et al. 1993) and alternative explanations may be equally plausible. It is apparent, however, that all rodents do not respond to predator odors in the same fashion, and additional studies are needed to clarify the use of heterospecific odors by Peromyscus spp. and Apodemus spp. and to identify the mechanisms responsible for the evolution of odor avoidance as an antipredator strategy.

\section{Acknowledgments}

Field assistance was provided by S. Persson, F. Durrance, and M. Lindquist. B. Wunder and L. McEwen loaned traps. We gratefully acknowledge the generous support of the National Science Foundation Long-Term Ecological Research Project (BSR-9011659 to I. Burke and W. Lauenroth), the Program for Ecological Studies at Colorado State University, and the American Museum of Natural History. The United States Department of Agriculture Agricultural Research Service permitted us to use the Central Plains Experimental Range site. Our procedures were approved by the Animal Care and Use Committee at Colorado State University. J. Kelly, N. McIntyre, J. Miller, R. Schooley, P. Sharpe, R. Weeks, L. Stapp, L. Drickamer, B. Wunder, and several anonymous reviewers provided comments on earlier drafts of the manuscript.

\section{References}

Armstrong, D.M. 1972. Distribution of mammals in Colorado. Univ. Kans. Mus. Nat. Hist. Monogr. No. 3.

Bailey, V., and Sperry, C.C. 1929. Life history and habits of grasshopper mice, genus Onychomys. U.S. Dep. Agric. Tech. Bull. No. 145.

Boonstra, R., Rodd, F.H., and Carleton, D.J. 1982. Effect of Blarina brevicauda on the trap response of Microtus pennsylvanicus. Can. J. Zool. 60: 438-442.

Coffin, D.P., and Lauenroth, W.K. 1990. A gap dynamics simulation model of succession in a semiarid grassland. Ecol. Modell. 49: 229-266.

Cole, H.F., and Wolfe, H.H. 1970. Laboratory evaluation of aggressive behavior of the grasshopper mouse (Onychomys). J. Pharm. Sci. 59: 969-971.

Daly, M.D., Wilson, M.I., and Behrends, P. 1980. Factors affecting rodents' responses to odours of strangers encountered in the field: experiments with odor-baited traps. Behav. Ecol. Sociobiol. 6: 323-329.

Dickman, C.R. 1992. Predation and habitat shift in the house mouse Mus domesticus. Ecology, 73: 313-322.

Dickman, C.R., and Doncaster, C.P. 1984. Responses of small mammals to red fox (Vulpes vulpes) odour. J. Zool. (1965-1984), 204: 521-531.

Drickamer, L.C. 1984. Captures of two species of Peromyscus at live traps baited with male and female odors. J. Mammal. 65: $699-702$.

Drickamer, L.C., Mikesic, D.G., and Shaffer, K.S. 1992. Use of odor baits in traps to test reactions to intra- and interspecific chemical cues in house mice living in outdoor enclosures. J. Chem. Ecol. 18: 2223-2250.
Egoscue, H.J. 1960. Laboratory and field studies of the northern grasshopper mouse. J. Mammal. 41: 99-110.

Epple, G., Mason, J.L., Nolte, D.L., and Campbell, D.L. 1993. Effects of predator odors on feeding in the mountain beaver (Aplodontia rufa). J. Mammal. 74: 715-722.

Erlinge, S. 1987. Predation and noncyclicity in a microtine population in southern Sweden. Oikos, 50: $347-352$.

Flake, L.D. 1971. An ecological study of rodents in a shortgrass prairie in northeastern Colorado. Ph.D. dissertation, Washington State University, Pullman.

Getz, L.L., Larson, C.M., and Lindstrom, K.A. 1992. Blarina brevicauda as a predator on nestling voles. J. Mammal. 73: $591-596$.

Gorman, M.L. 1984. The response of prey to stoat (Mustela erminea) scent. J. Zool. (1965-1984), 202: 419-423.

Grant, W.E., and Birney, E.C. 1979. Small mammal community structure in North American grasslands. J. Mammal. 60: 23-36.

Gurnell, J., and Little, J. 1992. The influence of residual trap odour on catching woodland rodents. Anim. Behav. 43: 623-632.

Henttonen, H., Oksanen, T., Jortikka, A., and Haukisalmi, V. 1987. How much do weasels shape microtine cycles in the northern Fennoscandian taiga? Oikos, 50: 353-365.

Heske, E.J., Brown, J.H., and Mistry, S. 1994. Long-term experimental study of a Chihuahuan desert rodent community: 13 years of competition. Ecology, 75: 438-445.

Horner, B.E., Taylor, J.M., and Padykula, H.A. 1965. Food habits and gastric morphology of the grasshopper mouse. J. Mammal. 45: $513-535$.

Jędrzejewski, W., Jędrzejewska, B., and McNeish, E. 1992. Hunting success of weasels Mustela nivalis and escape tactics of forest rodents in Bialowieza National Park. Acta Theriol. 37: $319-328$.

Jędrzejewski, W., Rychlik, L., and Jędrzejewska, B. 1993. Responses of bank voles to odours of seven species of predators: experimental data and their relevance to natural predator-vole relationships. Oikos, 68: 251-257.

Lindquist, M.D., Stapp, P., and Lauenroth, W.K. 1995. Monitoring studies of small mammal populations on the Shortgrass Steppe Long-Term Ecological Research site. Bull. Ecol. Soc. Am. 76(Suppl. 3): 357-358.

Madzer, E., Capone, M.R., and Drickamer, L.C. 1976. Conspecific odors and trappability of deer mice (Peromyscus leucopus noveboracensis). J. Mammal. 57: 607-609.

McCarty, R. 1978. Onychomys leucogaster. Mamm. Species No. 87. pp. 1-6.

Merkens, M., Harestad, A.S., and Sullivan, T.P. 199I. Cover and efficacy of predator-based repellents for Townsend's vole, Microtus townsendii. J. Chem. Ecol. 17: 401-412.

Montgomery, W.I. 1989. Peromyscus and Apodemus: patterns in similarity in ecological equivalents. In Advances in the study of Peromyscus (Rodentia). Edited by G.L. Kirkland, Jr. and J.N. Layne. Texas Tech University, Lubbock. pp. 293-366.

Nolte, D.L., Mason, J.R., Epple, G., Aronov, E., and Campbell, D.L. 1994. Why are predator urines aversive to prey? J. Chem. Ecol. 20: $1505-1516$.

Rebar, C., and Conley, W. 1983. Interactions in microhabitat use between Dipodomys ordii and Onychomys leucogaster. Ecology, 64: $984-988$.

Robinson, I. 1990. The effect of mink odour on rabbits and small mammals. In Chemical signals in vertebrates. Vol. 5. Edited by D.W. MacDonald, D. Müller-Schwarze, and S.E. Natynczuk. Oxford University Press, Oxford. pp. 566-572.

Ruffer, D.G. 1965. Burrows and burrowing behaviour of Onychomys leucogaster. J. Mammal. 46: 241-247.

Ruffer, D.G. 1968. Agonistic behavior of the northern grasshopper mouse (Onychomys leucogaster breviauritus). J. Mammal. 49: $481-487$. 
SAS Institute Inc. 1989. SAS/STAT user's guide, version 6.0. 4th ed. SAS Institute, Inc., Cary, N.C.

Sinclair, A.R.E., Olsen, P.D., and Redhead, T.D. 1990. Can predators regulate small mammal populations? Evidence from house mouse outbreaks in Australia. Oikos, 59: 382-392.

Stoddart, D.M. 1976. Effect of the odour of weasels (Mustela nivalis L.) on trapped samples of the prey. Oecologia, 22: 439-441.

Stoddart, D.M. 1980. Some responses of a free living community of rodents to the odors of predators. In Chemical signals: vertebrates and aquatic invertebrates. Edited by D. MüllerSchwarze and R.M. Silverstein. Plenum Press, New York. pp. $1-10$.

Stoddart, D.M. 1983. Odor as a component of trap entry behaviour in small rodents. In Chemical signals in vertebrates. Vol. 3. Edited by D. Müller-Schwarze and R.M. Silverstein. Plenum Press, New York. pp. 223-233.

Stoddart, D.M., and Smith, P.A. 1984. Wood mice (Apodemus sylvaticus) can distinguish conspecific from heterospecific odors in the field. J. Chem. Ecol. 10: 923-928.

Stoddart, D.M., and Smith, P.A. 1986. Recognition of odourinduced bias in the live-trapping of Apodemus sylvaticus. Oikos, 46: $194-199$.
Sullivan, T.P., Crump, D.R., and Sullivan, D.S. 1988a. Use of predator odors as repellents to reduce feeding damage by herbivores. III. Montane and meadow voles (Microtus montanus and Microtus pennsylvanicus). J. Chem. Ecol. 14: 363-377.

Sullivan, T.P., Crump, D.R., and Sullivan, D.S. 1988b. Use of predator odors as repellents to reduce feeding damage by herbivores. IV. Northern pocket gophers (Thomomys talpoides). J. Chem. Ecol. 14: 379-389.

Swihart, R.K. 1991. Modifying scent-marking behavior to reduce woodchuck damage to fruit trees. Ecol. Appl. 1: 98-103.

Terman, C.R. 1993. Studies of natural populations of white-footed mice: reduction of reproduction at varying densities. J. Mammal. 74: $678-687$.

Vepsäläinen, K., and Savolainen, R. 1988. Causal reasoning in modelling multi-way contingency tables. Oikos, 53: $281-285$.

Vermeij, G.J. 1982. Unsuccessful predation and evolution. Am. Nat. 120: $701-720$.

Wuensch, K.L. 1982. Effect of scented traps on captures of Mus musculus and Peromyscus maniculatus. J. Mammal. 63: $312-315$.

Zimmerling, L.M., and Sullivan, T.P. 1994. Influence of mustelid semiochemicals on population dynamics of the deer mouse (Peromyscus maniculatus). J. Chem. Ecol. 20: 667-689. 